\title{
Use of hydrolysis prior to the chemical and thermomechanical modification of rice starch: alternative to traditional modification treatments
}

\author{
Uso de hidrólisis previa a la modificación química y termomecánica de almidón de arroz: \\ alternativa a las modificaciones tradicionales
}

\begin{abstract}
Nancy Paola Grajeda-Nieto', Mayra Márquez-Gómez¹, Tomás Galicia-García1*, Iván Alziri Estrada-Moreno², Mónica Elvira Mendoza-Duarte², Rubén Márquez-Meléndez', Martha Graciela Ruiz-Gutiérrez', Armando Quintero-Ramos', Beatriz Portillo-Arroyo ${ }^{1}$, Cesar Soto Figueroa ${ }^{1}$

Faculty of Chemical Science. University Campus II. Food Science and Technology Programme. Autonomous University of Chihuahua, Chihuahua, Chih. CP. 31125. Mexico.

2 Research Center of Advance Materials S.C. CIMAV-Chihuahua. Miguel de Cervantes 120, Complejo Industrial Chihuahua. Chihuahua, Chih. CP. 31136. Mexico.
\end{abstract}

\section{ABSTRACT}

Isolated rice starch (NS), was subjected to chemical and thermomechanical modification with (MHS) and without (MS) previous hydrolysis for the evaluation of the main starch properties such as degree of substitution (DS), color, water absorption and solubility index (WAI, WSI), viscosity, texture, thermal properties (differential scanning calorimetry DSC) and structural properties (infrared-IR, Xray-Rx analysis, and relative crystallinity index-ICR). The DS obtained in both starches was within the range allowed by the FDA for its safety use as food ingredient (0.01-0.2). The modification showed an increase in WAI and WSI values, being WAI value higher in MS (4.80) and WSI value higher in MHS (32.06). The viscosity of retrogradation showed a significant decrease $(P<0.05)$ in MHS (0.013) and MS (5.613), however, the hardness of starch gels decreased (60\%) while the adhesiveness decreased only in MS (66\%). The ICR in MHS and MS increased with regard to the NS. The presence of the acetyl group in the starch molecule was observed in the signals between 1650 to $1744 \mathrm{~cm}^{-1}$ confirming the esterification. The starches showed a high potential for its application as edible coatings and as wall material for microencapsulation.

Keywords: Modified starch, Native starch, Acetylation, Extrusion, Hydrolysis.

\section{RESUMEN}

Almidón de arroz aislado (AN), fue sometido a modificación química y termomecánica con hidrólisis previa (AMH) y sin hidrólisis previa (AM), para ser caracterizado en grado de sustitución (GS), color, índice de absorción y solubilidad en agua (IAA e ISA), así como sus propiedades reológicas (viscosidad, textura), térmicas (Calorimetría diferencial de barrido - DSC) y estructurales (Infrarrojo- IR, rayos X-Rx e índice de cristalinidad relativa-ICR). El GS obtenido en ambos almidones se encontró dentro del rango permitido por la FDA (0.01-0.2) siendo seguro como ingrediente alimenticio. La modificación mostró un incremento en IAA e ISA, obteniéndose el mayor valor de IAA en el AM (4.80) y de ISA en el AMH (32.06). La viscosidad de retrogradación presentó

*Autor para correspondencia: Tomás Galicia García

Correo electrónico: tgalicia@uach.mx

Recibido: 25 de mayo de 2020

Aceptado: 21 de septiembre de 2020 una disminución significativa $(P<0.05)$ en $\mathrm{AMH}(0.013)$ y AM (5.613), asi mismo la dureza de los geles de almidón decreció (60\%) mientras que la adhesividad disminuyó únicamente en AM (66 \%). El ICR en AMH y AM aumentó con respecto al AN. La presencia del grupo acetilo en la molécula de almidón se observó en las señales entre $1650-1744 \mathrm{~cm}^{-1}$, confirmando la esterificación. Los almidones evaluados presentan alto potencial para su uso como recubrimientos comestibles y como materiales de pared para microencapsulación.

Palabras clave: Almidón Modificado, Almidón nativo, Acetilación, Extrusión, Hidrólisis.

\section{INTRODUCTION}

Rice (Oryza sativa L.) is one of the most consumed cereals in the world after corn, wheat and barley. Two-thirds of the world population includes rice in their diet, and their annual demand increase to 480 million tons (USDA, 2015). During rice harvesting and processing, broken grains are obtained, that are not used as raw material for consumption. An added value can be given to those grains by using them as raw material for starch extraction (Colussi et al., 2015; Dias et al., 2010). The main structural component of rice grain is represented by the endosperm (93\%), which is constituted by a majority fraction of starch (90\%) (Jualiano y Tuaño, 2019). Starch is a polymer formed by glucose units linked by alpha-D- $(1,4)$ glucosidic bonds for the linear region corresponding to amylose, and alfa-D- $(1,6)$ for branched region corresponding to amylopectin (Thomas et al., 1999). These two polymers constitute most of the native starch granules and, in lower proportion, also contain lipids and minerals (Copeland et al., 2009).

The food industry has used starch as a raw material due to its high availability, since they are found in diverse vegetable sources such as cereals, tubers, and roots (Singh et al., 2004; Estrada-Girón et al., 2015), but also due to their high functionality when used as thickener and binder in the preparation of foods, including soups, sauces, baby foods, mayonnaise and bakery products (Eliasson, 2004). The high amylose content is suitable for food coatings such as fruit, 
potato chips, etc., while the amylopectin content is applied as a thickening, stabilizing and adhesion agent. Likewise, starch has been previously used for the microencapsulation of vanillin extract (Tari et al., 2002), liposoluble vitamins (LópezHernández, 2010) and oleoresins (dos Santos et al., 2005). Also, it is used as a wall material in conjunction with animal proteins and natural gums, which promotes the formation of porous spherical aggregates, allowing a better interaction with other raw materials, thus, achieving a wall material more resistant for for the production of food quality microcapsules (Aguilar et al., 2007). However, native starch is not able to cover the range of physical and chemical properties mentioned above in food processing, due to low solubility, instability at different temperatures and retrogradation susceptibility, resulting in syneresis and rigidity (Hagenimana et al., 2006). Therefore, to be used as a food industry ingredient, it is necessary to carry out different structural modifications, which can be of chemical, physical and / or enzymatic type (Amagliani et al., 2016; Bello et al., 2009).

The chemical modification is carried out through the introduction of functional groups in the glucose molecules that make up the starch. This modification decreases the amylose retrogradation and gelation tendency, increases the water retention capacity and hydrophobic properties (Eliasson, 2004; Zavareze et al., 2011). On the other hand, the physical modification consists of the application of physical factors such as pressure, temperature, humidity, and shearing forces, for which an extruder is mainly used (Hagenimana et al., 2006). This type of modification helps to decrease retrogradation since the applied thermomechanical treatment generates a pregelatinization of starch granules which makes it more soluble at room temperature, favoring stability during storage. Alcázar-Alay and Meireles et al. (2015) reported the main processes that are carried out in starch, including: a) chemical modification (acid hydrolysis, cationization, acetylation, crosslinking and oxidation), and physical modification (pre-gelatinization, hydrothermal and non-hydrothermal).

The objective of this research is to use an hydrolysis prior to the chemical and thermomechanical modification of rice starch, as an alternative method to traditional modification treatments, reducing the use of reagents, and evaluate the physicochemical, thermal, rheological and structural properties obtained during the modification in order to obtain a starch with functional properties adaptable to the needs of the food industry, especially as an edible coating and active ingredient in encapsulating matrices.

\section{MATERIALS AND METHODS Raw Material}

White rice (Bekers \& chefs, Mexico), obtained from the local market (Chihuahua, Mexico), was used as raw material, and $\mathrm{NaOH}$ (Macron Fine Chemicals ${ }^{\circledR}$, USA), $\mathrm{HCl}$ (J.T. Baker, USA) and ammonium hydroxide (J. T Baker, USA) were used as reagents.

\section{Obtaining rice flour and isolation of rice starch}

Rice grains were subjected to milling (Pulvex ${ }^{\circledR} 300$, Mexico), the flour obtained was sieved (RoTap ${ }^{\oplus}$ RX-29-E, W.S Tyler, USA) in mesh \#35 (500 $\mu \mathrm{m})$ and the gross fraction was subjected to milling again. The flour was stored in refrigeration $\left(4^{\circ} \mathrm{C}\right)$ until use.

The rice starch isolation was carried out using the methodology reported by dos Santos et al. (2005), where to the rice flour a solution of $\mathrm{NaOH}(0.25 \%)$ was added at a 1:6 (w/ v) ratio and kept under constant stirring for $1 \mathrm{~h}$. Subsequently, it was neutralized $(\mathrm{pH}=7)$ with a $\mathrm{HCl}(10 \%)$ solution and stored in a cold room $\left(5^{\circ} \mathrm{C}\right)$ for 24 hours to complete the sedimentation phase. After this time, the supernatant was removed by decanting and the precipitated starch was centrifuged (Centra CL3R, Thermo IEC, USA) at $4000 \mathrm{rpm}(2750 \mathrm{xg})$ for $10 \mathrm{~min}$. The sedimented starch was dried in an incubator with air circulation (Napco 603, USA) at $40{ }^{\circ} \mathrm{C}$ for $12 \mathrm{~h}$. Once dry, the sample was ground (Retsch $\mathrm{GmbH}$, Germany) until obtaining a particle size of $250 \mu \mathrm{m}$. The native starch (AN) obtained was stored in refrigeration $\left(4{ }^{\circ} \mathrm{C}\right)$ for subsequent modification, characterization and use.

\section{Modification of starch}

In order to evaluate the effect of chemical and thermomechanical treatment on starch, the native starch obtained was separated into two batches; the first one was subjected to a hydrolysis treatment (see next section) prior to modification by esterification and thermomechanical treatment (MHS); while the second batch was subjected to modification by esterification without hydrolysis, and then thermomechanically modified by the extrusion process (MS).

\section{Chemical modification of rice starch}

In this work, the starch hydrolysis was only carried out in the first batch according to the methodology suggested by Murúa-Pagola et al. (2009), where a suspension (30 \% solids) with a $\mathrm{HCl}$ solution (3.4\%) (JT Baker, USA) was kept under stirring at $50^{\circ} \mathrm{C}$ for $6 \mathrm{~h}$. Then, the $\mathrm{pH}$ was adjusted to 5.5 with a $\mathrm{NaOH}$ solution $(10 \%)$ and refrigerated $\left(4^{\circ} \mathrm{C}\right)$ for $12 \mathrm{~h}$. Subsequently, the supernatant was decanted, and the precipitated starch was centrifuged (Centra mod CL3R, Thermo IEC, USA) at $4000 \mathrm{rpm}(2750 \mathrm{~g} \mathrm{xg})$ for $10 \mathrm{~min}$ at $20^{\circ} \mathrm{C}$. The obtained starch was dried in an oven with air circulation (Napco 603, USA) for $12 \mathrm{~h}$ at $45^{\circ} \mathrm{C}$, and finally grinded to obtain a particle size of $250 \mu \mathrm{m}$ (Retsch GmbH, Germany). Once the hydrolysis was realized, the starch was subjected to esterification according to the methodology reported by Andreuccetti et al. (2012), with acetic anhydride (0.01\% v / p) in a ratio of $11 \mathrm{~g}$ of solution / $\mathrm{kg}$ of starch (previously adjusted to a humidity of $22 \%$ ). The starch was stored for $12 \mathrm{~h}$ at $5{ }^{\circ} \mathrm{C}$ and the $\mathrm{pH}$ adjusted in a range of 8.5 to 9 with a solution of $\mathrm{NaOH}(10 \%)$ before subjecting it to thermomechanical modification.

\section{Thermomechanical modification of rice starch}

Both batches of starch (with and without hydrolysis) were processed in a single screw extruder (Brabender PL 
22000 , Germany) with a 2:1 compression ratio, at a screw speed of $30 \mathrm{rpm}$, using a temperature profile of 60,80 and $100{ }^{\circ} \mathrm{C}$ in zones 1,2 and 3 , respectively. The obtained extrudate was dried at $50{ }^{\circ} \mathrm{C}$ until a humidity of $11 \%$ to finally be milled (Retsch $\mathrm{GmbH}$, Germany) until obtaining a particle size of $250 \mu \mathrm{m}$.

\section{Characterization of the extruded product}

The previously acetylated extrudate was characterized by the expansion index and bulk density analysis.

\section{Expansion Index (EI)}

El was determined according to methodology reported by Mendonça et al. (2000), where the diameter of the extrudate and the output diameter of the extruder were related to obtain El. This analysis was performed on 5 extruded products.

\section{Apparent density (AD)}

DA was realized according to methodology reported by Pérez-Navarrete et al. (2006). The length and diameter of the extruded products were measured. The apparent volume (V) was determined by the relation diameter and height. When the mass and the volume were related, the apparent density (AD) was determined. This analysis was performed on 5 extrudates.

\section{Degree of substitution (DS)}

DS was determinated by the methodology reported by Bello et al. (2010), wherein $1 \mathrm{~g}$ of acetylated starch was placed in a $250 \mathrm{~mL}$ flask, mixed with $50 \mathrm{~mL}$ of ethanol-water solution $(75 \% \mathrm{v} / \mathrm{v})$, and was stirred for $30 \mathrm{~min}$ at $50^{\circ} \mathrm{C}$. Once cold, $40 \mathrm{~mL}$ of $\mathrm{KOH}(0.5 \mathrm{~N})$ were added and stored for $72 \mathrm{~h}$, with occasional stirring. Next, each treatment was titrated with a standard solution of $\mathrm{HCl}(0.5 \mathrm{~N})$, using phenolphthalein as indicator. Simultaneously, a control sample was titrated using native starch. The measurements were made in triplicate and a mean value was reported, with its standard deviation. The percentage of acetylation and the degree of substitution were obtained by means of the following equations:

$$
\begin{gathered}
\% \text { Acetylation }=\frac{[m L(\text { blank })-m L(\text { sample })] x \text { normality of acid } \times 0.043 \times 100}{\text { weight of sample, } g(\text { dry basis })} \\
D S=\frac{162 \times \% \text { acetylation }}{4300-(42 \times \% \text { acetylation })}
\end{gathered}
$$

\section{Characterization of isolated and modified rice starch}

To evaluate the effects of rice starch modification in both batches (with and without hydrolysis) we evaluated the following properties, in comparison to isolated starch (unmodified):

\section{Physicochemical properties Color}

This analysis was carried out using a colorimeter (Konica Minolta ${ }^{\circledR}$ CR-410, Japan), previously calibrated, to determine the values of $L^{*}$ (Luminosity), $a^{*}$ (tendency to green -, or red + ) and $b^{*}$ (tendency to blue-, or yellow + ) and whiteness index (WI). Five repetitions of each sample were made.

\section{Water absorption index (WAI) and water solubility index (WSI)}

These analyses were realized based on the methodology proposed by Murúa-Pagola et al. (2009), where $2.5 \mathrm{~g}$ of sample was weighed in $50 \mathrm{~mL}$ falcon tubes and $30 \mathrm{~mL}$ of distilled water were added. The tubes were kept shaking for 30 min at $30{ }^{\circ} \mathrm{C}$ in an incubator (Labnet International, Inc. USA), then the samples were centrifuged at $4000 \mathrm{rpm}(2750 \mathrm{xg})$ for 10 min (Centra CL3R, Thermo IEC, USA). For determination of WAl, the weight of the solid residue was recorded and the ratio of the gain in weight was calculated, expressed as grams of water absorbed per grams of dry sample. For the WSI analysis, the supernatant was decanted in porcelain capsules at constant weight and was evaporated for 24 hours at 110 ${ }^{\circ} \mathrm{C}$ in an oven (Felisa, Mexico) with air circulation. The weight of the capsules with the residue was recorded and related to the original sample as a percentage (\%). Both analysis were performed in triplicate.

\section{Viscosity}

Viscosity was obtained using a temperature profile. For the temperature scanning, 3 ramps were made with 1 $\mathrm{Hz}$ frequency and an oscillating effort of $50.11 \mathrm{~Pa}$. The first ramp was of 25 to $90^{\circ} \mathrm{C}\left(10^{\circ} \mathrm{C} / \mathrm{min}\right)$, the second ramp was maintained at a temperature of $90^{\circ} \mathrm{C}$ for $10 \mathrm{~min}$, and the third ramp of 90 to $25^{\circ} \mathrm{C}\left(10^{\circ} \mathrm{C} / \mathrm{min}\right)$. With this analysis the maximum viscosity was obtained in the heating cycle (VM), minimum viscosity during the stability cycle (V90), as well as maximum viscosity (Ve) during the cooling cycle. Through the difference of $\mathrm{V} 90$ and $\mathrm{Ve}$, the retrogradation viscosity ( $\mathrm{Vr}$ ) was determined. The analysis was performed in duplicate and a mean value was reported, with its standard deviation. This analysis was performed in triplicate.

\section{Texture properties}

To evaluate the consistency of the gels containing modified and native starches, we used the methodology reported by Hleap \& Velasco (2010) using a TA-XT plus Texture Analyzer (Texture Technologies, USA). Before the analysis, 25 $\mathrm{g}$ of sample were gelatinized (AN, AMH, AM) by adding 150 $\mathrm{mL}$ of water and maintaining constant agitation for 2 min at $50{ }^{\circ} \mathrm{C}$; then the temperature was increased to $92{ }^{\circ} \mathrm{C}$ for 5 min, and finally it was cooled to $50^{\circ} \mathrm{C}$ for $1 \mathrm{~min}$. The prepared gel was maintained at a refrigeration temperature of $5^{\circ} \mathrm{C} /$ $24 \mathrm{~h}$. The texture analysis was performed using a $30^{\circ}$ acrylic conical geometry (TA-17a, stable Micro System, USA), to measure the compression at a $10 \mathrm{~mm}$ distance and a speed of 5 $\mathrm{mm} / \mathrm{s}$. The test was performed twice at the same point. This analysis was done in duplicate. 


\section{Thermal Properties \\ Differential scanning calorimetry (DSC)}

It was carried out according to the methodology reported by Liu et al. (2009). To analyze the starch gelatinization temperature, 3 to $4 \mathrm{mg}$ were placed in aluminum capsules of $40 \mu \mathrm{L}$ adding $20 \mu \mathrm{L}$ of deionized water and closed hermetically. The capsules were placed in the calorimeter (TA Instrument Q-200, Crawley, UK) previously calibrated with indium and sapphire. They were brought to a temperature range of 20 to $130^{\circ} \mathrm{C}$, at a heating rate of $5^{\circ} \mathrm{C} / \mathrm{min}$. This analysis was done in duplicate.

\section{Structural Properties \\ Infrared spectroscopy with Fourier Transforms (FTIR)}

The infrared spectra obtained from the native and modified starches were analyzed using an infrared spectrophotometer (Spectrum GX Model FT-IR, Perkin Elmer Brand) equipped with a $\mathrm{KBr}$ pill system. For each sample, 16 scans were collected with a resolution of $4 \mathrm{~cm}^{-1}$, interval $1 \mathrm{~cm}^{-1}$ and an average value was obtained. The region in which they were analyzed was from 400 to $4000 \mathrm{~cm}^{-1}$, each sample was made in triplicate.

\section{X-ray diffraction (XRD) and relative crystallinity index (ICR)}

XRD was realized according to the methodology described by Zazueta-Morales (2003), using an X-ray diffractometer (Rigaku, Ultima D / Max-2100 RigakuDenki Co., Ltd., Japan). The films obtained were ground to a particle size of less than $420 \mu \mathrm{m}$ (No. 40 mesh). The diffractograms were obtained by scanning at a Bragg angle of $5^{\circ}$ to $40^{\circ}$ on a $2 \theta$ scale, with 0.02intervals, operating at $30 \mathrm{kV}$ and $16 \mathrm{~mA}$, using CuKa radiation and a wavelength of $1.5406 \AA$. The relative crystallinity index was calculated according to the Heman method with modifications proposed by Rabek (1980), using the following ec (3):

$$
I C R=(A c) /(A a+A c)
$$

Where:

$\mathrm{ICR}=$ Relative crystallinity index.

$A c=$ Crystalline region area.

$\mathrm{A} a=$ Amorphous region area.

\section{Statistical analysis}

To determine the statistical differences between the analyzed starches (native and modified), a one-way experiment design was used $(p \leq 0.05)$ and for significant statistical differences, the means were compared with the Tukey test $(p \leq 0.05)$. Data from the different evaluations were analyzed using Minitab $17^{\circledR}$ statistical software.

\section{RESULTS AND DISCUSSION}

\section{Characterization of the extruded product}

The apparent density (AD) values of the modified starch were $1.23 \mathrm{~g} / \mathrm{mL}$ for MHS and $1.26 \mathrm{~g} / \mathrm{mL}$ for MS. Thymi et al. (2005) report that the AD tends to be higher as the residence time inside of extruder machine increases. This effect causes degradation in the molecular structure of amylopectin of the starch-based material, reduces radial expansion resulting in an increase of the density value. Chinnaswamy \& Hanna (1988), report AD values in native maize starches in a range of 0.163 to $0.348 \mathrm{~g} / \mathrm{mL}$, difference due to the amylose content present in each treatment, as well as to the thermomechanical process and time of residence to which the starches were subjected in the present study.

For the El response, the MHS (0.99) and MS (0.91) values (Table 1), indicate no expansion in the extrudate, representing a first indication that the process conditions did not damage the starch (Thymi et al., 2005), corroborated with the null color change in the product obtained by extrusion (Aguilar et al., 2007), degree of substitution (Murua-Pagola et al., 2009) and water absorption index (Mali et al., 2005) previously analyzed. Thymi et al. (2005) mention that the expansion index depends on the moisture content, the extrusion temperature, and the residence time of the sample; thus, the expansion index tends to decrease as the moisture content increases, reaching an optimum humidity to obtain an expansion between 15 and $18 \%$ (Thymi et al., 2005). This is because the moisture content changes the starch amylopectin molecular structure, reducing the elasticity and thus decreasing the radial expansion index, and therefore, an increase in temperature would significantly influence the expansion index value (Vainionpää, 1991). However, an expansion of the product was not observed, mainly due to the process conditions (moisture, temperature, and residence time) in the extrusion equipment, where the modification favored the opening of the amylopectin molecule, the interaction with water molecules, and the low pressure at the exit of the extruder die, which resulted in null expansion; hence the importance of conditioning the extruded sample by subsequent drying.

Table 1. Characterization' of the extruded rice modified starch (MHS, MS)based product.

Tabla 1. Caracterización ${ }^{1}$ del producto extrudido a base de almidón de arroz modificado (MHS, MS).

\begin{tabular}{lcc}
\hline Analysis & \multicolumn{1}{c}{ MHS } & MS \\
\hline Ac $\%^{3}$ & $2.14 \pm 0.023^{\mathrm{a} 2}$ & $2.47 \pm 1.466^{\mathrm{a}}$ \\
DS & $0.08 \pm 0.001155^{\mathrm{b}}$ & $0.13 \pm 0.000343^{\mathrm{a}}$ \\
El & $0.99 \pm 0.01^{\mathrm{a}}$ & $0.91 \pm 0.02^{\mathrm{b}}$ \\
$\mathrm{AD} \mathrm{g} / \mathrm{mL}$ & $1.23 \pm 0.005^{\mathrm{a}}$ & $1.26 \pm 0.01^{\mathrm{a}}$ \\
\hline
\end{tabular}

${ }^{1}$ Results are mean \pm standard error of the mean $(n=3)$.

${ }^{2}$ Different letters in rows represent significant differences $(p \leq 0.05)$ among means obtained by Tukey test.

${ }^{3} A c$ : Acetylation, DS: degree substitute, El: expansion index, AD: apparent density.

MS: Modified rice starch, MHS: modified rice starch with previous hydrolysis.

\section{Degree of substitution (DS)}

The modified starches obtained in the present study had degree of substitution values of 0.08 for MHS and 0.13 
for MS (Table 1). Rendón-Villalobos et al. (2010) report that the degree of substitution approved by the FDA for food use is 0.01 to 0.2 to provide better stability, thickening and texture. Both treatments are within the established parameters by the FDA (considered appropriate for human consumption). Phillips (1999) report a degree of substitution value of 1.12 in waxy maize starch using $2.25 \mathrm{~g}$ of acetic anhydride / 100 $\mathrm{g}$ of starch, while Murua-Pagola et al. (2009) reported values of 0.033 using the same concentrations and technique, presenting as a difference the use of the extrusion process, once conditioned with acetic anhydride. These values are related to the ones obtained in MHS, which potentiates its application as wall material in microcapsules development for food use. Vaclavik \& Christian (2002) mention that through the extrusion process, the starch pre-gelatinization carried out through the application of heat results in a starch that can be solubilized at room temperature. Likewise, through pregelatinization, the phenomenon of retrogradation is reduced which generates syneresis, in which the granular structure is lost, the native crystals are melted and their components (amylose and amylopectin) are partially disordered (Bello Pérez et al., 2006).

\section{Physicochemical properties of rice starch Color analysis, Water absorption and solubility Indeces (WAI, WSI)}

Table 2 shows values obtained from the color analysis $\left(L^{*}, a^{*}\right.$ and $b^{*}$, Whiteness Index WI), the Water Absorption and Solubility Indices (WAI, WSI) of starch, both native and modified by hydrolysis (MHS) and without hydrolysis (MS).

The NS presented a higher luminosity value (97.52) compared to MHS and MS, indicating for both cases that the raw material does not have wild seeds that could favor a reddish hue. In all cases, the high values obtained are indicative that flour and starch come from polished rice (Von Atzingen et al., 2005). Atzingen et al. (2005) reported $L^{*}$ values of 90.52 to 92.90 in flour obtained from polished rice, which indicates that the differences present in modified starches and native starch are probably due to the starch isolation process. The difference observed in the WI between starches is due to the heterogeneity present in the grains of the raw material. Aguilar-Palazuelos (2007) reported that changes in coloration may be related to degradation when severe temperature conditions occur during storage. This tendency did not occur in isolated starch (native starch NS) as corroborated by the $L^{*}$ value (Table 1). Martinez-Bustos et al. (2012) mention that through the extrusion process a rapid water transference to inside of the polymer molecules is generated, as well as an effect of the joint action of mechanical stress and pressure. However, when these conditions (including temperature) are severe can cause a structural destabilization (dextrinization) that is accompanied by the presence of a yellowish color, low WAI values, viscosity and high WSI rates. This effect did not occur in the modified starches (modified starch with hydrolysis MHS and modified starch without hydrolysis MS), where a slight tendency to yellow was observed. Gulati et al. (2016) mention that the coloration will depend on several factors including moisture and temperature, so that a temperature increase in the extrusion equipment can cause a dextrinization favoring, values with a red tendency. This effect was not observed in modified starch samples (Table 1), which indicate the presence of a treatment with high functionality and application for films elaboration.

Table 2. Physicochemical characterization' of native (NS) and modified rice starch (MHS, MS).

Tabla 2. Caracterización fisicoquímica' del almidón nativo (NS) y modificado de arroz (MHS, MS)

\begin{tabular}{lccc}
\hline Analysis & NS & MHS & MS \\
\hline $\mathrm{L}^{* 3}$ & $97.52 \pm 0.119^{\mathrm{a} 2}$ & $91.25 \pm 1.139^{\mathrm{b}}$ & $90.36 \pm 0.015^{\mathrm{b}}$ \\
$\mathrm{a}^{*}$ & $-0.45 \pm 0.01155^{\mathrm{b}}$ & $-0.73 \pm 0.03^{\mathrm{c}}$ & $0.14 \pm 0.00577^{\mathrm{a}}$ \\
$\mathrm{b}^{*}$ & $3.33 \pm 0.0058^{\mathrm{c}}$ & $6.31 \pm 0.04^{\mathrm{a}}$ & $5.003 \pm 0.0058^{\mathrm{b}}$ \\
WI & $86.15 \pm 0.119^{\mathrm{a}}$ & $70.13 \pm 0.958^{\mathrm{c}}$ & $84.13 \pm 0.018^{\mathrm{b}}$ \\
WAI & $2.37 \pm 0.0265^{\mathrm{c}}$ & $3.57 \pm 0.4029^{\mathrm{b}}$ & $4.80 \pm 0.1202^{\mathrm{a}}$ \\
WSI & $1.90 \pm 0.115^{\mathrm{c}}$ & $32.06 \pm 5.808^{\mathrm{a}}$ & $11.72 \pm 0.167^{\mathrm{b}}$ \\
\hline
\end{tabular}

'Results are mean \pm standard error of the mean $(n=5)$.

${ }^{2}$ Different letters in rows represent significant differences $(p \leq 0.05)$ among means obtained by Tukey test.

${ }^{3} L^{*}$ : luminosity; $a^{*}$ : tendency to green -, or red $+; b^{*}$ : tendency to blue-, or yellow +; WI: whiteness index; WAI: water absorption index, WSI: water solubility index

NS: native rice starch, MS: Modified rice starch, MHS: modified rice starch with previous hydrolysis.

The water absorption and solubility indexes (WAI and WSI, respectively) can be used as an indication of the degree of starch modifications by thermomechanical treatments (Rodríguez et al., 2006). Thus, the higher absorption index, the more water is absorbed by starch causing a lower solubility of sample. The native starch presented a lower capacity of water absorption which is reflected in its physicochemical properties (viscosity). The values obtained from WAI (2.37) and WSI (1.9) in NS are related with values reported by Murúa-Pagola et al. (2009) for WAI (3.45). The difference present in WAI is an indicative of the isolation process, since in the commercial process a standardized particle size is used, which gives it a greater degree of absorption. A difference between the native and the modified starch is observed for the WAI due to process conditions in the extrusion equipment, which can generate products with greater solubility (Harper, 1992). On the other hand, the increase in the solubility of the modified starch with previous hydrolysis is associated with the lixiviation of the starch chains through a continuous phase which is related to a partial disorganization of the starch components. The high energy generated by the friction inside the extruder causes the fragmentation in starch granules which involve increasing the WSI value (Martinez-Bustos et al., 2012). This tendency is related to the difference observed between the native starch treatment and modified, being MHS greater due to conditioning prior to the thermomechanical process. 


\section{Viscosity of starch}

The thermomechanical modification to which the starch was subjected by the extrusion equipment had the purpose of favoring the interaction of the acetyl group with the hydroxyl groups available in the molecule through mechanical stress and thermal treatment. In addition, to avoid the retrogradation of starch to the undergo pregelatinization during the process (Hagenimana et al., 2006). Murúa-Pagola et al. (2007) discuss that viscosity analysis is a useful tool in determining the degree of starch granules fragmentation due to the conditions or severity of the treatments used.

As the starch solution is heated under constant oscillating stress, an increase in viscosity begins to be observed as the starch granules begin to swell, obtaining the maximum viscosity peak. Once this point is reached, the low molecular weight polymers (amylose) begin to lixiviate resulting in the collapse of the granules and a decrease in viscosity (Tester et al., 2004). Table 3 shows that the viscosity of NS is greater than that of the modified starches; this difference of decrease is mainly due to chemical modification that the starch was subjected. Since the addition of acetyl groups to the glucose molecule reduces the intermolecular forces of the granule, this decreases the viscosity of the starch (Lawal, 2004). This reduction in viscosity coincides with studies reported by Enríquez et al. (2013) where they reported a decrease in viscosity in cassava starch modified with respect to the native. Retrogradation is an important parameter in the food industry because it allows a greater storage stability, and can be used in refrigerated foods, frozen foods, dressings, etc. (Singh et al., 2007). It was observed that for the modified starches there was a significant difference when the maximum viscosity values in the heating cycle (VM) and retrogradation $(\mathrm{Vr})$ decrease with respect to NS, product of the chemical and thermomechanical conditioning used. However, the difference in $\mathrm{Vr}$ values between modified starches (0.013 $\mathrm{Pa}^{*} \mathrm{~s}$ MHS and 5.61 $\mathrm{Pa}^{*}$ s MS) are due to the structural breakage by the chemical conditioning, which confers low viscosity values as well as a suitable functionality such as ingredient in the formulation of wall materials for microencapsulation.

Table 3. Viscosity analysis ${ }^{1}$ in native (NS) and modified rice starch (MHS, MS).

Tabla 3. Análisis de viscosidad' en almidón nativo (NS) y modificado de arroz (MHS, MS).

\begin{tabular}{lllll}
\hline \multicolumn{2}{l}{ Analysis } & \multicolumn{1}{c}{ NS } & \multicolumn{1}{c}{ MHS } & \multicolumn{1}{c}{ MS } \\
\hline VM & $(\text { Pa.s })^{3}$ & $151.93 \pm 38.73^{\mathrm{a} 2}$ & $0.03 \pm 0^{\mathrm{b}}$ & $37.57 \pm 7.7^{\mathrm{b}}$ \\
V90 & (Pa.s) & $34.163 \pm 3.99^{\mathrm{a}}$ & $0.023 \pm 0^{\mathrm{c}}$ & $15.57 \pm 7.19^{\mathrm{b}}$ \\
$\mathrm{Ve}$ & (Pa.s) & $54.313 \pm 7.65^{\mathrm{a}}$ & $0.037 \pm 0.01^{\mathrm{c}}$ & $21.183 \pm 9.13^{\mathrm{b}}$ \\
$\mathrm{Vr}$ & (Pa.s) & $20.15 \pm 5.032^{\mathrm{a}}$ & $0.013 \pm 0.008^{\mathrm{b}}$ & $5.613 \pm 2.243^{\mathrm{b}}$ \\
\hline
\end{tabular}

${ }^{1}$ Results are mean \pm standard error of the mean $(n=3)$.

${ }^{2}$ Different letters in rows represent significant differences $(p \leq 0.05)$ among means obtained by Tukey test.

${ }^{3}$ VM: Maximum viscosity in heating cycle. V90:maximum viscosity during the stability cycle. Ve: maximum viscosity during cooling cycle. Vr: retrogradation viscosity.

NS: native rice starch, MS: Modified rice starch, MHS: modified rice starch with previous hydrolysis.

\section{Volumen XXIII, Número 1}

Murúa-Pagola (2009) reported a maximum viscosity of 0.05 $\mathrm{Pa}^{*} \mathrm{~s}$ in phosphated waxy maize starch (with previous hydrolysis), so when compared to the MHS treatment, the viscosity is lower due to the modification made, as well as the source of the starch used.

\section{Texture Profile Analysis}

The texture properties of starch gels are important parameters to evaluate the performance of a starch in the food system, thus favoring the optimization of industrial processes and the development of new products (Singh et al., 2007). The modifications that were realized in the starches gave them different properties within which a lower tendency to form gels can be observed, obtaining a significant difference between the native starch and the modified starches where in both cases the values of hardness and adhesiveness were decreased (Table 4). This trend favors the use of modified starches as stabilizers in frozen foods, and for encapsulation (Singh et al., 2007).

Table 4. Texture profile analysis (TPA) ${ }^{1}$ in native (NS) and modified rice starch (MHS, MS).

Tabla 4. Perfil de análisis de textura (TPA)' en almidón nativo (NS) y modificado de arroz (MHS, MS).

\begin{tabular}{lccc}
\hline Analysis & NS & MHS & MS \\
\hline Hardness (N) & $0.33 \pm 0.01134 \mathrm{a} 2$ & $0.28 \pm 0.00163 \mathrm{~b}$ & $0.22 \pm 0.01797 \mathrm{c}$ \\
$\begin{array}{l}\text { Adhesiveness } \\
\text { (kg m2 s-2) }\end{array}$ & $-0.01 \pm 0.0006 \mathrm{a}$ & $-0.01 \pm 0.0015 \mathrm{a}$ & $-6.30 \pm 0.3853 \mathrm{~b}$ \\
Elasticity & $0.87 \pm 0.02053 \mathrm{a}$ & $0.78 \pm 0.04188 \mathrm{~b}$ & $0.82 \pm 0.01528 \mathrm{ab}$ \\
Cohesiveness & $0.69 \pm 0.02265 \mathrm{a}$ & $0.36 \pm 0.04668 \mathrm{~b}$ & $0.71 \pm 0.02566 \mathrm{a}$ \\
\hline
\end{tabular}

${ }^{1}$ Results are mean \pm standard error of the mean $(n=2)$.

${ }^{2}$ Different letters in rows represent significant differences $(p \leq 0.05)$ among means obtained by Tukey test.

NS: native rice starch, MS: Modified rice starch, MHS: modified rice starch with previous hydrolysis.

For the gel based in modified starch without hydrolysis, the hardness was reduced with respect to the native starch since a slight depolymerization was favored by acetylation and the thermomechanical effect, which causes a weakening of the gel. The same tendency was observed in the modified starch without hydrolysis in comparison with the native starch, where by means of the modification there was a $35 \%$ reduction in the hardness (Puncha-arnon et al., 2013). The lowest cohesive value (0.362) was observed in the hydrolyzed starch, mainly due to the fact that the swollen granules interrupt the starch gel network, which translates into a low association of the number of active zones in the polymer network (Casas Alencáster and Pardo-García, 2005). Regarding to adhesiveness, no significant differences were observed between NS and MHS, however a significant decrease in adhesiveness in the MS treatment was noted, which is directly related to the viscosity thereof, product of the interaction in the reactive sites of the glucose molecule with water through hydrogen bonds (Sothornvit et al., 2005). 


\section{Thermal properties}

Table 5 shows the values of onset temperature (To), gelatinization (Tp) and final (Tf), as well as the enthalpy $(\Delta \mathrm{H})$ of native rice starch, modified with hydrolysis and without hydrolysis. The thermal transition behavior shown by the native starch with a range of 72.1 to $80.12^{\circ} \mathrm{C}$ is similar to the values reported by Puncha-arnon \& Uttapap (2013) where the range goes from 69.4 to $77.3^{\circ} \mathrm{C}$. The increase in the peak temperature for the modified starches is mainly due to the amorphous region that contains the starch granule since the modification produces a destabilizing effect on the crystalline fusion, therefore the temperature has to be higher to melt the crystalline region (Gunaratne et al., 2002). Gonzalez-Soto et al. (2011) mention that the gelatinization temperatures of rice starch particles are indicative of the amount of crystalline regions present within the starch granule, since the gelatinization temperature reflects the energy required for achieve the loss of the crystal structure present in the granules.

Table 5. Differential scanning calorimetry (DSC) ${ }^{1}$ in native (NS) and modified rice starch (MHS, MS).

Tabla 5. Calorimetria diferencial de barrido (DSC) de almidón native (NS) y modificado de arroz (MHS, MS).

\begin{tabular}{lccc}
\hline Analysis & NS & MHS & MS \\
\hline To $\left({ }^{\circ} \mathrm{C}\right)^{3}$ & $72.10 \pm 0.049^{\mathrm{b} 2}$ & $75.46 \pm 0.311^{\mathrm{a}}$ & $70.515 \pm 0.785^{\mathrm{b}}$ \\
$\mathrm{Tp}\left({ }^{\circ} \mathrm{C}\right)$ & $76.41 \pm 0.085^{\mathrm{c}}$ & $81.94 \pm 0.099^{\mathrm{a}}$ & $76.765 \pm 0.064^{\mathrm{b}}$ \\
$\mathrm{Tf}\left({ }^{\circ} \mathrm{C}\right)$ & $80.12 \pm 1.534^{\mathrm{b}}$ & $88.77 \pm 0.184^{\mathrm{a}}$ & $84.165 \pm 1.039^{\mathrm{b}}$ \\
Enthalpy $(\mathrm{J} / \mathrm{g})$ & $4.51 \pm 0.2404^{\mathrm{b}}$ & $3.83 \pm 0.0403^{\mathrm{c}}$ & $6.5325 \pm 0.1237^{\mathrm{a}}$ \\
\hline
\end{tabular}

${ }^{1}$ Results are mean \pm standard error of the mean $(n=2)$.

${ }^{2}$ Different letters in rows represent significant differences $(p \leq 0.05)$ among means obtained by Tukey test.

${ }^{3} \mathrm{To}=$ onset temperature, $\mathrm{Tp}=$ gelatinization temperature, $\mathrm{Tf}=$ final temperature, $\Delta \mathrm{H}^{\circ}=$ enthalpy of gelatinization.

NS: native rice starch, MS: Modified rice starch, MHS: modified rice starch with previous hydrolysis.

Enthalpy values were obtained for the native starch of $4.51\left(\mathrm{Jg}^{-1}\right)$ and for the modified starch of $6.53\left(\mathrm{Jg}^{-1}\right)$, presenting a same tendency (decrease in enthalpy values) as reported by Colussi et al. (2015), where values were obtained for the native $4.51\left(\mathrm{Jg}^{-1}\right)$ and modified $6.5\left(\mathrm{Jg}^{-1}\right)$ starch. The differences are due to the fact that in the modified treatment a structural disorganization was generated, which it requires more energy at a lower heat of fusion (Sha et al., 2012). Due to the introduction of a functional group, in this case the acetyl, a decrease in the gelatinization temperatures of the modified starch was observed, compared to the modified starch with hydrolysis due to the weakening of the intergranular forces during the extrusion caused a disruption of the structure (Colussi et al., 2015). The enthalpy value of MHS is diminished with respect to other starches, probably because there is a glucose chain fragmentation, product of hydrolysis, so the degree of interaction between the starch chains needs less heat energy to melt (Gunaratne et al., 2002). Likewise, the introduction of acetyl groups to the starch breaks the hydrogen bridges, weakening the granular structure, thus decreasing the enthalpy of gelatinization (Prieto-Méndez et al., 2010). Low enthalpies of gelatinization reduce energy costs during food processing. In this research, an enthalpy reduction (3.83 $\left.\pm 0.04 \mathrm{Jg}^{-1}\right)$ in MHS was observed, however, the gelatinization temperature was higher than the rest of the starches (81.94 $\pm 0.09{ }^{\circ} \mathrm{C}$ ) with significant difference, probably due to the hydrophobic groups (acetyl) present in the modified starch, when forming inclusion complexes with the amylose, which causes the gelatinization temperatures to move to higher values as the concentration of these groups increases (Morales-Martínez, 2014).

\section{Structural properties \\ Infrared spectroscopy with Fourier Transforms (FTIR)}

The spectra obtained in NS samples (Figure1) using a sweep of 4000 to $500 \mathrm{~cm}^{-1}$, coincide with that reported by Prieto-Méndez et al. (2010) in samples of acetylated barley starch. For the native starch there were bands of characteristic groups of starch molecule related to the $\mathrm{OH}$-group, corresponding to the band at $3270 \mathrm{~cm}^{-1}$ and to the stretch of $\mathrm{CH}$ related with the band at $2950 \mathrm{~cm}^{-1}$, the bands at 1650 $\mathrm{cm}^{-1}$ correspond to the scissors vibration of two $\mathrm{OH}$ bonds (Mano et al., 2003), while in starches modified by acetylation there are bands between $898-1250 \mathrm{~cm}^{-1}$, which belong to the stretch of the CO group, the signal shown at $1245 \mathrm{~cm}^{-1}$ corresponds to the stretching of the acetyl CO groups. In the $3000-3900 \mathrm{~cm}^{-1}$ range, an enlarged band was observed, assigned to the vibrations by stretching or tension of the hydroxyl groups and the vibrations by flexion is shown approximately at $1650 \mathrm{~cm}^{-1}$ when introducing acetyl groups to the starch this will cause vibrations by bending due to the steric effect (Rivas-González et al., 2009). The increase in the signal between 1650 and $1744 \mathrm{~cm}^{-1}$ is attributed to the stretching of the $\mathrm{C}=\mathrm{O}$ carbonyl ester group, that indicates acetylation (Xu et al., 2004). Previous work such as that of Prieto-Méndez et al. (2010) and Rendón-Villalobos et al. (2010), this signal is increased since the degree of substitution was higher, due to the increase in the reactivity of acetic anhydride.

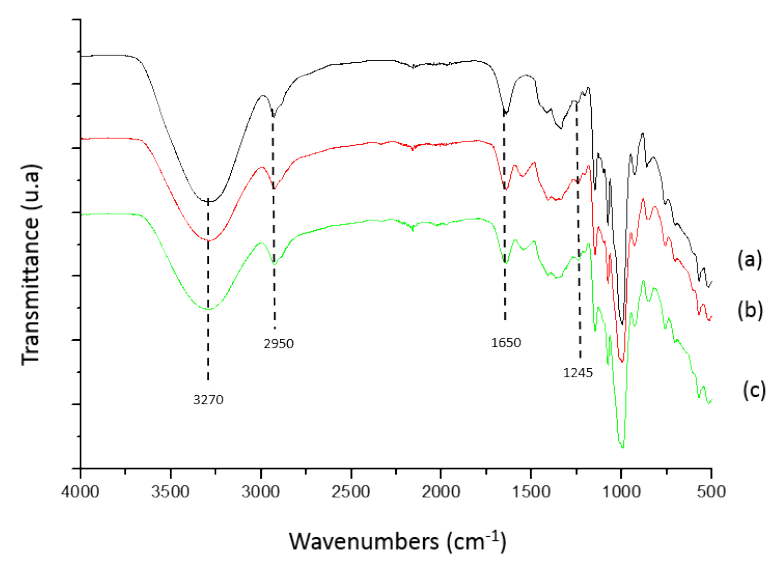

Figure 1. Infrared spectrum (FTIR) of rice starch: a) native (NS), b) modified (MS), and c) modified with previous hydrolysis (MHS).

Figura 1. Espectro infrarrojo (FTIR) de almidón de arroz: a) nativo (NS), b) modificado (MS) y c) modificado con hidrólisis previa (MHS). 
Through physical modification the characteristics of rice starch are improved, such as retrogradation and solubilization (Hagenimana et al., 2006; López et al., 2010). Because acetylated starch has a greater capacity to retain water in its matrix, this agrees with the results obtained for solubility, paste consistency and absorption. It is reflected an increase in these results attributed to having a more organized structure (Chel-Guerrero et al., 2012).

\section{X-ray diffraction (XRD) and relative crystallinity index (ICR)}

By X-ray diffraction analysis is possible to define the degree of crystallinity of a starch due to crystalline nature, and it is based on the ordered structure of amylopectin molecules inside the granule, this analysis provides information on the modification of starches (Moorthy, 2002; Sebio, 2003).

Figure 2 shows difractograms corresponding to the native starch in which a pattern type A was observed characteristic in starches, which contain longer amylopectin branched chains corresponding to starches from cereals (Vermeylen, 2004; Thomas et al., 1999) with peaks in values $2 \theta$ of $15.14,17.59,19.9,23.14,26.7^{\circ}$. These values are similar to those reported by Wang et al. (2002) in rice starch where values were $2 \theta$ of $15,17.5,19,23,27.5^{\circ}$. For MHS and MS treatments, peaks were observed at $2 \theta$ values of $15.04,18,20.05,23.20$ and 15.12, 17.82, 19.95, 22.94 ${ }^{\circ}$, with a characteristic type $B$ pattern resulting from the structural modification, which is perceived as a loss of resolution when presenting a greater narrowing and change in intensity.

The relative crystallinity index indicates the degree of crystallinity of a material (Sebio, 2003) which is determined by the relationship between the crystalline area and the total area. The crystallinity index of modified starches MHS (57\%) and MS (59\%) increased with respect to the native starch NS $(40.43 \%)$. This is due to the degree of depolymerization, since



Figure 2. $X$ ray diffraction patterns of rice starch: a) native (NS), b) modified (MS) and c) modified with previous hydrolysis (MHS).

Figura 2. Patron de difracción de rayos $X$ de almidón de arroz: a) nativo (NS), b) modificado (MS) y modificado con hidrólisis previa (MHS). the modification did not affect the amorphous part of the granule of starch but the crystalline part (Xie et al., 2005). The same behavior is shown in tapioca starches, where increases in crystallinity are observed when carrying out a modification in the granule structure (Chinachotic et al., 2001). In Figure 3, similar characteristic patterns of cereals are shown where the intensity is decreased in the modified starches.

\section{CONCLUSIONS}

An improvement in the physicochemical, thermal and rheological properties of modified rice starch with and without hydrolysis prior to esterification and thermomechanical treatment was obtained, making it suitable for use as functional ingredient in the preparation of edible materials as coating and encapsulating agents. The degree of substitution obtained in modified starch is within the ranges permitted by the FDA, which guarantees its innocuousness for human consumption. The obtained values of apparent density and expansion index in the extruded products are an indicator that the process conditions during the extrusion were controlled without affecting their functional properties of the treatments analyzed, as can be confirmed by not presenting a loss of color, increase of the water absorption index and low values of water solubility index, in comparison with the native starch. Through infrared spectroscopy, differential scanning calorimetry and X-ray diffraction analyses, it was possible to evaluate the presence of greater functionality due to the joint effect of the chemical and thermomechanical modification with respect to native starch. Modified hydrolyzed starch (MHS) treatment due to low viscosity (optimum for the preparation of emulsions), solubility and gelatinization temperature (ideal to be used in a spray drying process) presented a greater functionality to be used as wall material in the microencapsulation of food ingredients. The modified starch without hydrolyzing (MS) treatment presented a high viscosity, cohesiveness and low solubility, characteristics that make it more suitable for films elaboration and edible coatings.

This research shows the importance of the process for starch modification to adapt it to different food matrices, in addition to reiterating the use of rice starch as a natural alternative to commercial ingredients, since its modification by extrusion suggests a more environmentally friendly process to decrease the use of reagents compared to those currently used at industrial level.

\section{ACKNOWLEDGMENT}

Two first authors would like to thank to the National Council of Science and Technology (CONACyT) for providing the funding in the Master Science and Food Technology studies at the Chihuahua State University Posgrade Program, included in Excellence Posgrades. The authors want to thanks Erika López for the viscosity measurements and Daniel Lardizabal for the DSC and FTIR measurements. 


\section{REFERENCES}

Aguilar-Palazuelos, E., Martínez-Bustos, F., Jiménez-Arévalo, O. A., Galicia-García, T., and Delgado-Rangel, J. A. 2007. Potentiality of some natural fibres and native starch for making biodegradable materials in: Food engineering research developments, (T.P. Klening, ed), pp 279-294. Nova Science Publishers, New York.

Alcázar-Alay, S.C., and Meireles, A.A. 2015. Physicochemical properties, modifications and applications of starches from different botanical sources. Food Science and Technology Campinas 35, 215-236.

Amagliani, L., O'Regan, J., Kelly, A. L., and O'Mahony, J. A. 2016. Chemistry, structure, functionality and applications of rice starch. Journal of Cereal Science 70, 291-300.

Andreuccetti, C., Carvalho, R. A., Galicia-García, T., MartínezBustos, F., González-Núñez, R., and Grosso, C. R. F. 2012. Functional properties of gelatin-based films containing Yucca schidigera extract produced via casting, extrusion and blown extrusion processes: A preliminary study. Journal of Food Engineering 113, 33-40.

Bello-Pérez, L. A., Agama-Acevedo, E., Zamudio-Flores, P. B., Mendez-Montealvo, G., \& Rodriguez-Ambriz, S. L. 2010. Effect of low and high acetylation degree in the morphological, physicochemical and structural characteristics of barley starch. LWT - Food Science and Technology 43, 1434-1440.

Bello-Pérez, L. A., and Paredes-López, O. 2009. Starches of some food crops, changes during processing and their nutraceutical potential. Food Engineering Reviews 1, 50-65.

Bello Pérez, L. A., González Soto, R. A., Sánchez Rivero, M. M., Gutiérrez Meraz, F., and Vargas Torres, A. 2006. Extrusión de almidones de fuentes no convencionales para la producción de almidón resistente. Agrociencia 40, 441-448.

Casas-Alencáster, B. N., and Pardo-García, D. G. 2005. Análisis de perfil de textura y propiedades de relajación de geles de mezclas almidón de maíz ceroso entrecruzado-gelana. Revista Mexicana de Ingeniería Química 4, 107-121.

Colussi, R., El Halal, S. L. M., Pinto, V. Z., Bartz, J., Gutkoski, L. C., da Rosa Zavareze, E., and Dias, A. R. G. 2015. Acetylation of rice starch in an aqueous medium for use in food. LWT - Food Science and Technology 62, 1076-1082.

Copeland, L., Blazek, J., Salman, H., and Tang, M. C. 2009. Form and functionality of starch. Food Hydrocolloids 23, 15271534.

Chel-Guerrero, L., Pérez-Flores, V., Betancur-Ancona, D., and Dávila-Ortiz, G. 2012. Functional Properties of Flours and Protein Isolates from Phaseolus lunatus and Canavalia ensiformis Seeds. Journal of Agricultural and Food Chemistry 50, 584-591.

Chinachotic, P., and Varavinita, S. 2001. A study of some physicochemical properties of high-crystalline tapioca starch. Starch/Stärke 53, 577-581.

Chinnaswamy, R., and Hanna, M. A. 1988. Relationship between amylose content and extrusion-expansion properties of com starches. Cereal Chemistry, 65, e147.

Dias, A. B., Müller, C. M. O., Larotonda, F. D. S., and Laurindo, J. B. 2010. Biodegradable films based on rice starch and rice flour. Journal of Cereal Science, 51, 213-219.

dos Santos, A. B., Fávaro-Trindade, C. S., and Grosso, C. R. F. 2005. Preparo e caracterização de microcápsulas de oleorresina de páprica obtidas por atomização. Ciência e Tecnologia de Alimentos 25, 322-326.
Eliasson, A.C. 2004. Starch in food: Structure, function and applications: Woodhead Publising. USA.

Enríquez C, M., Velasco M, R., and Fernández Q, A. 2013. Caracterización de almidones de Yuca nativos y modificados para la elaboración de empaques biodegradables. Biotecnología en el Sector Agropecuario y Agroindustrial 11, 21-30.

Estrada-Girón, Y., Martínez-Preciado, A.H., Michel, C.R., and Soltero, J.F.A. 2015. Characterization of Extruded Blends of Corn and Beans (Phaseolus vulgaris) Cultivars: Peruano and Black-Querétaro under Different Extrusion Conditions. International Journal of Food Properties 18, 2638-2651.

González-Soto, R. A., de la Vega, B., García-Suarez, F. J., AgamaAcevedo, E., and Bello-Pérez, L. A. 2011. Preparation of spherical aggregates of taro starch granules. LWT-Food Science and Technology 44, 2064-2069.

Gulati, P., Weier, S. A., Santra, D., Subbiah, J., and Rose, D. J. 2016. Effects of feed moisture and extruder screw speed and temperature on physical characteristics and antioxidant activity of extruded proso millet (Panicum miliaceum) flour. International Journal of Food Science \& Technology 51, 114 122.

Gunaratne, A., and Hoover, R. 2002. Effect of heat-moisture treatment on the structure and physicochemical properties of tuber and root starches. Carbohydrate Polymers 49, 425437.

Hagenimana, A., Ding, X., and Fang, T. 2006. Evaluation of rice flour modified by extrusion cooking. Journal of Cereal Science 43, 38-46.

Harper, J. M., Tribelhorn, R. E. 1992. Expansion of native cereal starch extrudates. In: Food Extrusion Science and Technology, (J.L. Kokini., C.T. Ho y M.V. Karwe, eds.), pp. 653667. Marcel Dekker Inc, New York.

Hleap, J. I., and Velasco, V. A. 2010. Análisis de las propiedades de textura durante el almacenamiento de salchichas elaboradas a partir de tilapia roja (Oreochromis sp.). Biotecnología en el Sector Agropecuario y Agroindustrial 8, 46-56.

Juliano, B. O., and Tuaño, A.P. 2019. Gross structure and composition of the rice grain. En: Rice (Fourth Edition). Jinsong Bao (ed), pp 31-53. AACC International Press.

Lawal, O. S. 2004. Composition, physicochemical properties and retrogradation characteristics of native, oxidised, acetylated and acid-thinned new cocoyam (Xanthosoma sagittifolium) starch. Food Chemistry 87, 205-218.

Liu, H., Xie, F., Yu, L., Chen, L., and Li, L. 2009. Thermal processing of starch-based polymers. Progress in Polymer Science 34, 1348-1368.

López Hernández, O. D. 2010. Microencapsulación de sustancias oleosas mediante secado por aspersión. Revista Cubana de Farmacia 44, 381-389.

López, O.V., Zaritzky, N. E., and García, M. A. 2010. Physicochemical characterization of chemically modified corn starches related to rheological behavior, retrogradation and film forming capacity. Journal of Food Engineering 100, 160-168.

Mali, S., Sakanaka, L. S., Yamashita, F., and Grossmann, M. V. E. 2005. Water sorption and mechanical properties of cassava starch films and their relation to plasticizing effect. Carbohydrate Polymers 60, 283-289.

Mano, J. F., Koniarova, D., and Reis, R. L. 2003. Thermal properties of thermoplastic starch/synthetic polymer blends with potential biomedical applicability. Journal of Materials 
Science: Materials in Medicine 14, 127-135.

Martínez-Bustos, F., Aguilar-Palazuelos, E., Galicia-García, T., Telis, V. 2012. Thermoplastic Behavior of Biopolymers during Extrusion, Biopolymer Engineering in Food Processing. V.R.N. Telis (ed), pp 245-278. CRC Press. USA.

Mendonça, S., Grossmann, M.V.E., Verhé, R. 2000. Corn Bran as a Fibre Source in Expanded Snacks, LWT - Food Science and Technology 33 (1), 2-8.

Moorthy, S. N. 2002. Physicochemical and functional properties of tropical tuber starches: a review. Starch-Stärke 54, 559592.

Morales Martínez, L. E. 2014. Morfometría de los granos de arroz (Oryza sativa L.) y caracterización fisicoquímica, estructural y reológica de las harinas integrales de las variedades MorelosA-92 y Koshihikari y de seis líneas provenientes de estas. Tesis de Maestría en Ciencias en Desarrollo de Productos Bióticos. Instituto Politécnico Nacional, México.

Murúa-Pagola, B., Beristain-Guevara, C. I., and Martínez-Bustos, F. 2007. Application of phosphorylated waxy maize starch in the microencapsulation of flavors: characterization and stability. In: Journal of Food Engineering Research Developments (T.P. Klening ed.), Pp. 979-971. Nova Science Publishers, New York.

Murúa-Pagola, B., Beristain-Guevara, C. I., and Martínez-Bustos, F. 2009. Preparation of starch derivatives using reactive extrusion and evaluation of modified starches as shell materials for encapsulation of flavoring agents by spray drying. Journal of Food Engineering 91, 380-386.

Pérez-Navarrete, C., Cruz-Estrada, R. H., Chel-Guerrero, L. and D, B.-A. 2006. Physical characterization of extruders prepared with corn flour mixtures QPM (Zea mays L.) and lima beans (Phaseolus lunatus L.). Mexican Journal of Chemical Engineering 5, 145-155.

Phillips, D. L., Liu, H., Pan, D., and Corke, H. 1999. General application of raman spectroscopy for the determination of level of acetylation in modified starches. Cereal Chemistry 76, 439-443.

Prieto-Méndez, J., Trejo-Cárdenas, C. L., Prieto-García, F., MéndezMarzo, M. A., Bello-Pérez, L. A., and Román-Gutiérrez, A. D. 2010. Acetilación y caracterización del almidón de cebada. Revista Latinoamericana de Recursos Naturales 6, 32-43.

Puncha-arnon, S., and Uttapap, D. 2013. Rice starch vs. rice flour: Differences in their properties when modified by heatmoisture treatment. Carbohydrate Polymers 91, 85-91.

Rabek, J. F. 1980. Applications of wide-angle X-ray diffraction (WAXD) to the study of the structure of polymers. In: Experimental methods in polymer chemistry (H.F. Mark, ed.) pp. 123-140. Wiley-Interscience, New York.

Rendón-Villalobos, R., García-Hernández, E., Güizado-Rodríguez, M., Salgado-Delgado, R., and Rangel-Vázquez, N. A. 2010. Obtención y caracterización de almidón de plátano (Musa paradisiaca L.) acetilado a diferentes grados de sustitución. Afinidad, 67, 548.

Rivas-González, M., Zamudio-Flores, P. B., and Bello-Pérez, L. A. 2009. Efecto del grado de acetilación en las características morfológicas y fisicoquímicas del almidón de plátano. Revista Mexicana de Ingeniería Química 8, 291-297.

Santos, B. D., Fávaro-Trindade, A., Grosso, C. S. F. and Raimundo, C. 2005. Preparo e Caracterização de Microcápsulas de Oleoresina de Páprica Obtidas por Atomização. Ciência e Tecnologia de Alimentos, 25, 322-326
Sebio, L. 2003. Desenvolvimento de plástico biodegradável a base de amido de milho e gelatina pelo processo de extrusão: avaliação das propriedades mecânicas, térmicas e de barreira.

Sha, X. S., Xiang, Z. J., Bin, L., Jing, L., Bin, Z., Jiao, Y. J. \& Kun, S. R. 2012. Preparation and physical characteristics of resistant starch (type 4) in acetylated indica rice. Food Chemistry 134, 149-154.

Singh, N., Chawla, D., Singh, J. 2004. Influence of acetic anhydride on physicochemical, morphological and thermal properties of corn and potato starch. Food Chemistry 86, 601-608.

Singh, J., Kaur, L., and McCarthy, J. 2007. Factors influencing the physico-chemical, morphological, thermal and rheological properties of some chemically modified starches for food applications-a review. Food Hydrocolloids, 21:1-22.

Sothornvit, R., and Krochta, J.M. 2005. Plasticizer in edible films and coatings, in Innovations. In J.H. Han (ed), Innovations in foods packings.403-428. Amsterdan. The Netherlands: Elservier.

Tari, T. A., and Singhal, R. S. 2002. Starch-Based Spherical Aggregates: Stability Of A Model Flavouring Compound, Vanillin Entrapped.

Tester, R. F., Karkalas, J., and Qi, X. 2004. Starch-Composition, Fine structure And Architecture. Journal of Cereal Science, 39(2), 151-165.

Thymi, S., Krokida, M. K., Pappa, A., and Maroulis, Z. B. 2005. Structural Properties of Extruded Corn Starch. Journal of Food Engineering, 68(4), 519-526.

Thomas, T. D. J., and Atwell, W. A. 1999. Starches. Eagan Press Handbook.

Vaclavik, V. A., and Christian, E. W. 2002. Fundamentos de Ciencia de los Alimentos: Editorial Acribia, México.

Vermeylen, R., Goderis, B., Reynaers, H and Delcour, J.A. 2004. Amylopectin Molecular Structure Reflected in Macromolecular Organization of Granular Starch. Biomacromolecules 5, 1775-1786.

Von Atzingen, M. C., and Machado Pinto and Silva, M. E. 2005. Evaluación de la Textura y Color de Almidones y Harinas en preparaciones sin Gluten. CyTA-Journal of Food 4, 319-323.

Wang, Y.J., Wang, L., Shephard, D., Wang, F., and Patindoll, J. 2002. Properties and structures of flours and starches from whole, broken, and yellowed rice kernels in a model study. Cereal Chemistry 79, 383.

Xie, S. X., Liu, Q., and Cui, S. W. 2005. Starch modification and applications: CRC Press, USA.

Xu, Y., Miladinov, V., and Hanna, M. A. 2004. Synthesis and characterization of starch acetates with high substitution 1. Cereal Chemistry 81, 735-740.

Zavareze, E. D. R., and Dias, A. R. G. 2011. Impact of heat-moisture treatment and annealing in starches: A review. Carbohydrate Polymers, 83(2), 317-328.

Zazueta-Morales, J. J. 2003. Extrusión de maíz (Zea mays L.) azul: efecto del hidróxido de calcio sobre las propiedades fisicoquímicas y funcionales. Tesis de Doctorado. Universidad Autónoma de Querétaro. 